\title{
LIGHT MICROSCOPIC EVALUATION OF APOPTOSIS IN PREMALIGNANT AND MALIGNANT LESIONS OF THE UTERINE CERVIX
}

\author{
Subhash Bhardwaj', Shiffali Sarngal2, Mehnaz Choudhary33 \\ ${ }^{1}$ Associate Professor, Department of Pathology, GMC, Jammu. \\ 2 Demonstrator, Department of Forensic Medicine, GMC, Jammu. \\ ${ }_{3}^{3}$ Medical Officer, Directorate of Health, Jammu and Kashmir.
}

\section{ABSTRACT}

\section{CONTEXT}

Cell proliferation and cell death are important phenomenon responsible for the control of cell number in normal and neoplastic tissue. Simple indices can be used to measure cell proliferation and apoptosis.

\section{AIMS}

To study cell death by apoptosis and cell proliferation in metaplastic, mild, moderate, severe dysplastic intraepithelial cervical lesions and carcinomas of cervix.

\section{SETTINGS AND DESIGN}

Hospital based Retrospective and Prospective study.

\section{MATERIAL AND METHODS}

This study was conducted over a period of 3 years where total of 100 lesions were evaluated for Apoptotic Index (AI), Mitotic Index (MI) and Turnover Index (TI).

\section{STATISTICAL ANALYSIS}

Student's T test

\section{RESULTS}

Mean AI, MI, TI increased from metaplastic to dysplastic to frank malignant lesions. Significant difference was found in MI (P 0.0003) between mild dysplasia vs. moderate dysplasia and squamous metaplasia vs. moderate/severe dysplasia (P 0.000009). AI, MI and TI showed highly significant difference (P 0.0000001) between premalignant and malignant group of lesions. Among the malignant group TI show significant difference between well differentiated and less well differentiated group.

\section{CONCLUSIONS}

Proliferative activity of a lesion is a reliable indicator of its malignant potential and together with the apoptotic count gives an idea about the net growth of a tumor.

\section{KEYWORDS}

Apoptosis, Cervix, CIN, Apoptotic Index, Mitotic Index, Turnover Index.

HOW TO CITE THIS ARTICLE: Bhardwaj S, Sarngal S, Choudhary M. Light microscopic evaluation of apoptosis in premalignant and malignant lesions of the uterine cervix. J. Evolution Med. Dent. Sci. 2016;5(16):774-777, DOI: 10.14260/jemds/2016/180

\section{INTRODUCTION}

Apoptosis is defined as a programmed cell death that does not elicit any inflammatory reaction. ${ }^{1}$ There are many studies available in the literature, which have evaluated the apoptosis by light microscopy in variety of human tumors, yet there are very few studies available from India, which have studied the apoptosis with light microscopy in premalignant and malignant lesions of uterine cervix. Hence, we planned to conduct this study on cervical lesions. Moreover, cervix is commonly affected with various conditions including disorders of epithelial maturation, hyperplasias, benign tumors, dysplasias and malignant neoplasms. ${ }^{2}$

Financial or Other, Competing Interest: None.

Submission 08-01-2016, Peer Review 06-02-2016,

Acceptance 12-02-2016, Published 24-02-2016.

Corresponding Author:

Shiffali Sarngal,

H. No-39, Canal Road

Rajinder Nagar

Jammu, J\& K.

E-mail: drshiffalissarngal@gmail.com

DOI: $10.14260 /$ jemds/2016/180
Proliferative activity of a tumor depends on stimulatory growth signals from various oncogenes and probably is accompanied by inactivation of one or more tumor suppressor genes. ${ }^{3}$ Cell proliferation can be measured by several indices such as mitotic index, PCNA, Ki-67 and AgNOR count. However, it should not be forgotten that neoplastic growth depends on factors influencing the cell proliferation and cell death. Cell death occurs either by necrosis or by apoptosis. Apoptosis is recognized as a physiological mechanism for controlling cell numbers and its subversion is thought to contribute to carcinogenesis. Apoptosis can be measured by various methods such as light microscopy, electron microscopy, flow cytometry, electrophoresis, in situ nick translation and TUNEL method (Tdt-mediated dUTP biotin nick labeling). 4,5

The present study is based purely on morphology as it is a fairly reliable, easily practiced and inexpensive method for detection of both apoptosis and mitosis. ${ }^{1}$ We all know that neoplastic growth depends not only on cell death (Apoptosis), but also on cell proliferation which is an important feature of dysplasia and carcinoma. 
Simple Index, i.e. Mitotic Index can be used to measure cell proliferation. We also studied the correlation of Turnover Index (TI) in different grades of cervical lesions. We have chosen the term Turnover Index (TI) as sum of Apoptotic Index (AI) and the Mitotic Index (MI), (TI=AI+MI).

\section{MATERIAL AND METHODS}

The study was conducted over a period of 3 yrs. and consisted of two parts-retrospective study for a period of 2 yrs. and prospective for a period of $1 \mathrm{yr}$. For the retrospective study a total number of 56 cases of cervical lesions were reported, the slides of which were retrieved from the histopathology achieves and screened. The prospective study included all the cervical biopsy specimens, which were fixed in $10 \%$ buffered formalin, dehydrated in ascending grades of alcohol, cleared in xylene and finally embedded in paraffin; 2-5 micron thick paraffin sections of uniform thickness were cut and stained with hematoxylin and eosin. During this period, a total of 44 cases were reported.

The hematoxylin-eosin stained slides were screened under 40X objective and 10X eyepiece, but the final count of apoptotic cells were carried out under high magnification (Oil immersion $x 100$ lens). From each section, 5 fields devoid of any preservation and fixation artifact, inflammation and necrosis were selected. Apoptotic cells, bodies in the stroma around the tumors were not counted. In each section, 1000 tumor cells were evaluated for apoptotic cell and apoptotic bodies. Apoptotic cells with characteristic features of cell shrinkage, condensation and deep eosinophilia of cytoplasm and pyknotic, round to crescentic or irregular nucleus were identified. ${ }^{6}$ Apoptotic bodies which typically appear as tiny, round and pyknotic nuclear fragments are seen scattered amongst the tumor cells and occasionally forming small clusters were also identified.7

Apoptotic Index (AI) was calculated as the number of apoptotic cells and apoptotic bodies, expressed as a percentage of the total number of non-apoptotic tumor cells counted in each case. Similarly Mitotic Index (MI) was also calculated by counting mitosis among 1000 tumor cells or from dysplastic cells in CIN or from metaplastic lesions in cervical biopsy specimen. Turnover Index (TI) was obtained from sum of $\mathrm{MI}$ and $\mathrm{AI}$, i.e. (TI=MI+AI). After calculating the apoptotic index, mitotic index and turnover index, they were correlated with different grades of the cervical lesions.

\section{RESULTS}

Out of 100 cases studied, 35 (35.0\%) were premalignant and $65(65.0 \%)$ were malignant. Maximum number of premalignant lesions, i.e. 15 (42.85\%) belonged to age group 35-44 yrs. and that of malignant lesions, i.e. 22 (33.84\%) belonged to age group 35-44 yrs. [Table 1]. The mean AI, MI and TI increased progressively from metaplasia to dysplasia to carcinoma [Table 2]. However on statistical analysis, AI and TI among all four grades of premalignant lesions were found to be statistically insignificant. MI between the group mild dysplasia vs. moderate dysplasia ( $p$ value 0.0003 ) and between squamous metaplasia vs. moderate dysplasia/severe dysplasia ( $p$ value 0.000009 ) showed statistically highly significant difference [Table 3]. Mean AI, MI and TOI which increased from premalignant to malignant lesions was found to be statistically highly significant (p value 0.0000001 ).
For the purpose of knowing how these malignant lesions behaved among themselves, we divided the malignant group into well differentiated (Keratinizing squamous cell carcinoma) and less well differentiated group (Nonkeratinizing squamous cell carcinoma, Adenocarcinoma, Adenosquamous carcinoma). Statistical analysis revealed a significant difference in TOI between the two subgroups of malignant lesions.

\section{DISCUSSION}

The study was conducted on 100 cases of various cervical lesions. Mean AI, MI and TOI were evaluated with increasing grades of lesions from squamous metaplasia to dysplasia to carcinoma.

For the purpose of statistical inference, we divided our cases into following groups to compare our result with various studies.

Group I: Squamous metaplasia vs. mild dysplasia, Group II: Mild dysplasia vs. moderate dysplasia,

Group III: Moderate dysplasia vs. severe dysplasia,

Group IV: Squamous metaplasia vs. Moderate/Severe dysplasia.

In the present study mean $\mathrm{AI}, \mathrm{MI}$ and TOI increased from metaplasia to dysplasia, but on statistical analysis difference was found to be insignificant. There was not much difference in apoptosis and mitosis between squamous metaplasia and mild dysplasia. This insignificant difference could be attributed to the lack in number of cases in moderate and severe dysplasia, as our study involves both retrospective and prospective analysis and maximum number of patients reported with carcinoma cervix. MI shows statistical significant difference in Group II (Mild dysplasia vs. Moderate dysplasia) and Group IV (Squamous metaplasia vs. moderate/severe dysplasia).

This shows that number of mitosis increases with increasing grades of lesion. Our results are correlating with the results shown by Dey P, et al. (2000) who reported statistically insignificant difference in mean AI and MI in Group II (Mild dysplasia vs. moderate dysplasia) and Group III (Moderate dysplasia vs. severe dysplasia).

Sagol 0, et al.8 did not find any statistically significant difference between CIN-I and CIN-II as well as between CIN-II and CIN-III groups in terms of apoptotic and mitotic cell counts. Mitotic cell counts were found statistically higher in CIN-III group when compared with CIN-I and CIN-II groups together coinciding with the results of our study between Group II (Mild vs. moderate dysplasia) and Group III (Moderate vs. severe dysplasia). We have also compared the mean AI, MI and TOI of malignant lesion as a whole group with the premalignant lesion and found that the $\mathrm{AI}, \mathrm{MI}$ and TOI increased as the nature of lesion changed from premalignant to malignant. This difference between both the groups was very highly significant (P 0.0000001).

This finding of our study suggests how the histological behaviour of the lesions suddenly changes as they cross the thin red line between the premalignant and the malignant types. This also re-established the fact that these highly proliferating lesions also have high rate of cell turnover. Besides this proliferative and apoptotic indices have also been found to be useful to distinguish between benign and malignant lesions of the cervix.9,10 
Vijaya et al. ${ }^{2}$ also reported significant difference $(\mathrm{P}<0.01)$ in mean $\mathrm{AI}$ and $\mathrm{MI}$ with increasing grades of lesion from dysplasia to carcinoma cervix.

Dey $\mathrm{P}$ et $\mathrm{al}^{3}$ reported that mean AI (P 0.0028), MI (P 0.0018) and TOI (P 0.0014) increases from lower to higher grades of CIN to carcinoma of cervix. The difference was found to be highly significant, correlating our results with their study. Sagol 0, et al. ${ }^{8}$ also concluded that both apoptosis and mitosis are markedly increased in progression towards malignancy in cervical epithelium. Mitotic cell counts may be helpful in predicting the extent of the disease in squamous cell carcinoma cervix.

In the present study, we further subdivided the malignant lesions into well differentiated (KSCC) and less well differentiated (NKSCC, Adenocarcinoma, Adenosquamous Carcinoma Lesions) and compared the AI, MI and TOI. There was no statistically significant difference between the AI and MI of both the groups. The difference in TOI was however statistically significant. Since the majority of malignant lesions were in well differentiated group ( 45 cases, i.e. $69.23 \%$ ), the relationship between the various indices could not be accurately determined and this is attributed to the statistically insignificant difference in $\mathrm{AI}$ and $\mathrm{MI}$.
Our results correlated with Sagol 0, et al. ${ }^{8}$ who also reported that there was no statistically significant difference in the apoptotic and mitotic cell counts between nonkeratinizing and Keratinizing Squamous Cell Carcinoma (KCC). They also showed that in the Squamous Cell Carcinoma (SCC) group, apoptotic cell counts did not show significant difference between tumor stages, but mitotic counts were significantly higher in advanced stage tumors.

In conclusion, apoptotic cells and mitosis can be readily and accurately demonstrated on routine $\mathrm{H}$ and $\mathrm{E}$ stained sections. AI and MI are the simplest technique can be employed in any laboratory.

- Besides squamous epithelial lesions of the cervix, proliferative and apoptotic indices have also been found to be useful to distinguish between benign and malignant lesions of the cervix.

- Observed increase in apoptotic cell with the grade of lesion, suggests a mechanism whereby apoptosis help to eliminate cells that have been produced in excess.

- Proliferative activity of a lesion is a reliable indicator of its malignant potential and together with the apoptotic count gives an idea about the net growth of a tumor.

\begin{tabular}{|c|c|c|c|c|c|c|c|c|c|c|}
\hline & \multicolumn{4}{|c|}{ Premalignant } & & \multicolumn{4}{|c|}{ Malignant } & \multirow[b]{2}{*}{ Total } \\
\hline $\begin{array}{l}\text { Age group } \\
\text { in years }\end{array}$ & $\begin{array}{l}\text { Squamous } \\
\text { metaplasia }\end{array}$ & $\begin{array}{c}\text { Mild } \\
\text { dysplasia }\end{array}$ & $\begin{array}{l}\text { Moderate } \\
\text { dysplasia }\end{array}$ & $\begin{array}{c}\text { Severe } \\
\text { dysplasia }\end{array}$ & Total & $\begin{array}{l}\text { Keratinis- } \\
\text { ing } \\
\text { squamous } \\
\text { cell } \\
\text { carcinoma }\end{array}$ & $\begin{array}{l}\text { Non- Keratinising } \\
\text { squamous cell } \\
\text { carcinoma }\end{array}$ & $\begin{array}{c}\text { Adenoc } \\
\text { arcinom } \\
\text { a }\end{array}$ & $\begin{array}{l}\text { Adeno- } \\
\text { squamous } \\
\text { carcinoma }\end{array}$ & \\
\hline $25-34$ & 3 & 2 & 1 & 0 & $6(17.1 \%)$ & 2 & 1 & 0 & 0 & $\begin{array}{c}3 \\
(4.61 \%) \\
\end{array}$ \\
\hline $35-44$ & 8 & 6 & 0 & 1 & $15(42.85 \%)$ & 17 & 4 & 1 & 0 & $22(33.84 \%)$ \\
\hline $45-54$ & 4 & 0 & 0 & 0 & $4(11.42 \%)$ & 12 & 1 & 1 & 1 & $15(23.07 \%)$ \\
\hline $55-64$ & 4 & 1 & 1 & 1 & $7(20.0 \%)$ & 7 & 7 & 1 & 1 & $16(45.71 \%)$ \\
\hline $65-75$ & 1 & 2 & 0 & 0 & $3(8.57 \%)$ & 7 & 2 & 0 & 0 & $9(13.8 \%)$ \\
\hline
\end{tabular}

\begin{tabular}{|c|c|c|c|c|}
\hline Diagnosis & No. of Cases & $\begin{array}{c}\text { Apoptotic } \\
\text { index }\end{array}$ & Mitotic index & Turnover index \\
\hline Squamous metaplasia & 20 & $0.68 \pm 0.42$ & $0.02 \pm 0.05$ & $0.71 \pm 0.44$ \\
\hline Mild dysplasia & 11 & $0.58 \pm 0.65$ & $0.009 \pm 0.03$ & $0.6 \pm 0.67$ \\
\hline Moderate dysplasia & 2 & $1 \pm 0.7$ & $0.15 \pm 0.07$ & $1 \pm 0.56$ \\
\hline Severe dysplasia & 2 & $1.1 \pm 0.7$ & $0.3 \pm 0.14$ & $1.2 \pm 0.84$ \\
\hline Keratinising squamous cell carcinoma & 45 & $3.37 \pm 1.14$ & $0.55 \pm 0.56$ & $3.94 \pm 1.340$ \\
\hline Non-keratinising squamous cell carcinoma & 15 & $2.87 \pm 1.41$ & $0.47 \pm 0.35$ & $3.35 \pm 1.45$ \\
\hline Adenocarcinoma & 3 & $1.8 \pm 1.5$ & $0.16 \pm 0.11$ & $1.93 \pm 1.46$ \\
\hline Adenosquamous carcinoma & 2 & $3.65 \pm 1.2$ & $0.25 \pm 0.35$ & $3.8 \pm 0.84$ \\
\hline Table 2: Shows apoptotic indices, mitotic indices and turnover indices in various histological groups of cervical epithelial \\
lesions
\end{tabular}

\begin{tabular}{|c|c|c|c|c|c|c|}
\hline & $\begin{array}{c}\text { Squamous } \\
\text { metaplasia vs. mild } \\
\text { dysplasia }\end{array}$ & $\begin{array}{c}\text { Mild dysplasia vs. } \\
\text { moderate } \\
\text { dysplasia }\end{array}$ & $\begin{array}{c}\text { Moderate } \\
\text { dysplasia vs. } \\
\text { severe dysplasia }\end{array}$ & $\begin{array}{c}\text { Squamous metaplasias } \\
\text { vs. mod/severe } \\
\text { dysplasia }\end{array}$ & $\begin{array}{c}\text { Premalignant vs. } \\
\text { malignant } \\
\text { (p value) }\end{array}$ & $\begin{array}{c}\text { Well differentiated vs. } \\
\text { less differentiated } \\
\text { (p value) }\end{array}$ \\
\hline $\begin{array}{c}\text { Apoptotic } \\
\text { index }\end{array}$ & 0.606 & 0.447 & 0.8995 & 0.1434 & $0.0000001^{* *}$ & 0.08 \\
\hline $\begin{array}{c}\text { Mitotic } \\
\text { index }\end{array}$ & 0.51 & $0.0003^{* *}$ & 0.3081 & $0.000009^{* *}$ & $0.00000049^{* *}$ & 0.28 \\
\hline $\begin{array}{c}\text { Turnover } \\
\text { index }\end{array}$ & 0.58 & 0.44 & 0.8057 & 0.14 & $0.0000001^{* *}$ & $0.05^{*}$ \\
\hline \multicolumn{7}{r|}{$\begin{array}{c}\text { Table 3: Mean Apoptotic indices, Mitotic indices, Turnover indices and } \\
\text { Statistical inference (Student's t-test) between different parameters }\end{array}$} \\
\hline \multicolumn{7}{r}{} \\
\hline
\end{tabular}

*- Significant. ** Highly significant 


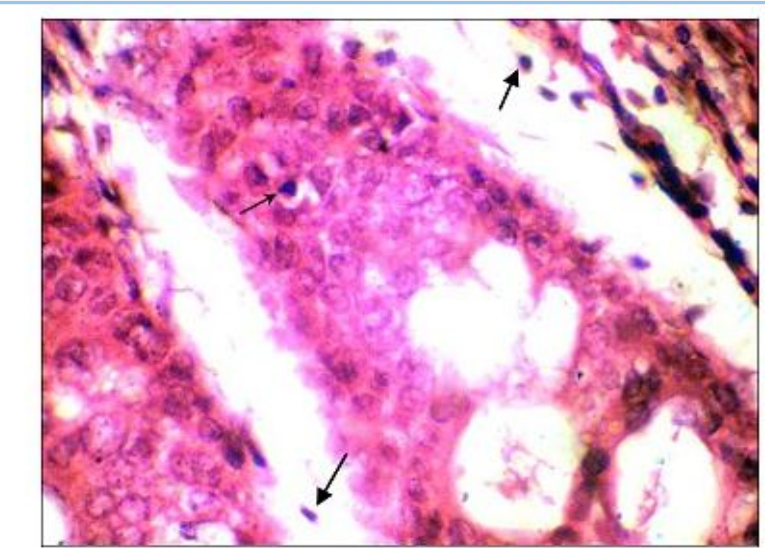

Photomicrograph from a case of Squamous metaplasia cervix showing apoptotic cells (arrows) (H\&E 20X10x).

\section{Fig. 1}

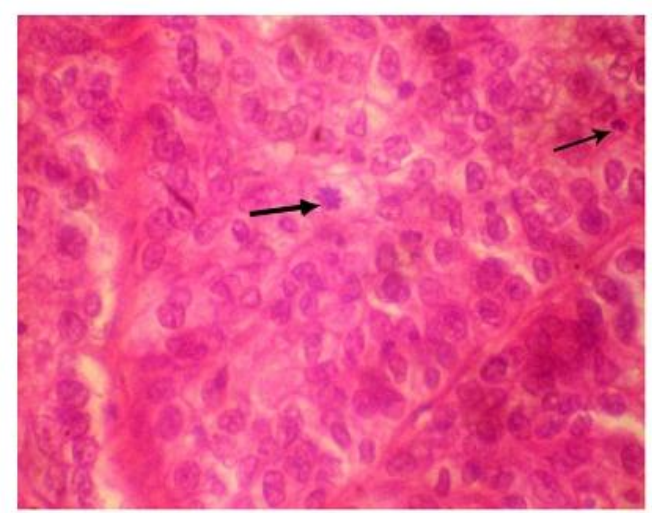

Photomicrograph from a case of Non Keratinising squamous cell carcinoma cervix showing multipolar abnormal mitosis (thick arrow) and apoptotic cell (thin arrow). (H\&E 40X10x).

\section{Fig. 2}

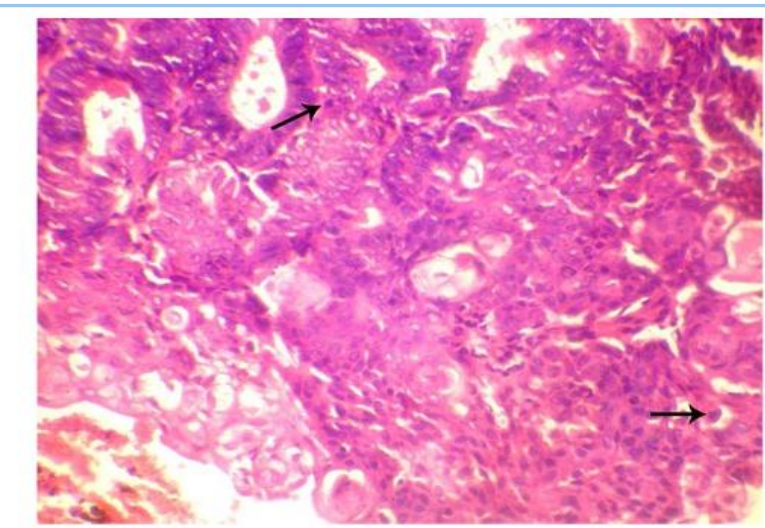

Photomicrograph from a case of Adenosquamous carcinoma cervix.Many apoptotic cells (thin arrows) are being seen. (H\&E 20X10x).

\section{REFERENCES}

1. Soini Y, Paakko P and Lehto VP. Histopathological evaluation of apoptosis in cancer. American Journal of Pathology 1998;153:1041-1053.

2. Vijaya V Mysorekar, David S, Rao SG. Proliferative and apoptotic indices in squamous epithelial lesions of the cervix. Bahrain Medical Bulletin 2008;30(4).

3. Dey P, Das R, Sabuddin. Correlations between apoptotic and proliferative indices in cervical intraepithelial neoplasia and carcinoma. Indian J Pathol Microbiol 2000 Jul;43(3):271-5.

4. Gavrieli Y, Sherman Y. Identification of programmed cell death in situ via specific labelling of nuclear DNA fragmentation. The Journal of Cell Biology 1992;119:493-501.

5. Langlois NE, Eremin 0 and Heys SD. Apoptosis and prognosis in cancer: rationale and relevance. J R Coll Surg Edinb 2000;45:211-219.

6. Jain A, Maheshwari V, Alam K, et al. Apoptosis in premalignant and malignant squamous cell lesions of the oral cavity: a light microscopic study. Indian Journal of Pathology and Microbiology 2009;52(2):164-166.

7. Biscotti CV, Hart WR. Apoptotic bodies: a consistent morphological feature of endocervical adenocarcinoma in situ. Am J Surg Pathol 1998 Apr;22(4):434-9.

8. Sagol O, Yorukoglu K, Sagol S, et al. Apoptotic and mitotic index in squamous cell carcinomas and premalignant lesions of the uterine cervix. International Journal of Surgical Pathology, July 1, 1999;7(3):155-160.

9. Moritani S, Ioffe OB, Sagae S, et al. Mitotic activity and apoptosis in endocervical glandular lesion. Int J Gynecol Pathol 2002 Apr;21(2):125-33.

10. Mandal AK, Verma D, Mohanta PK, et al. Prognostic significance of apoptotic index in squamous cell carcinoma of oral cavity with special reference to TNM stage, histological grade and survival. Indian J Pathol Microbiol 2001 Jul;44(3):257-9.

Fig. 3 